\author{
Asian Journal of \\ Medical and Biological Research \\ ISSN 2411-4472 (Print) 2412-5571 (Online) \\ www.ebupress.com/journal/ajmbr
}

\title{
Article \\ Evaluation of growth performance of Brahman cross calves to local environment of Bangladesh
}

\author{
Md Azizul Haque, Mst. Fatematuzzohora, Md. Azharul Hoque*and Md. Younus Ali \\ Department of Animal Breeding and Genetics, Bangladesh Agricultural University, Mymensingh 2202, \\ Bangladesh \\ *Corresponding author: Professor Dr. Md. Azharul Hoque, Department of Animal Breeding and Genetics, \\ Bangladesh Agricultural University, Mymensingh-2202, Bangladesh. E-mail: azharhoque@yahoo.com
}

Received: 07 June 2016/Accepted: 20 June 2016/ Published: 30 June 2016

\begin{abstract}
The present study was conducted using growth performance data on 624 Brahman cross (25\%) calves collected from three villages adjacent to Bangladesh Agricultural University, Mymensingh, Bangladesh. Growth performance data of 289 Brahman cross $(50 \%)$ calves were also collected from record sheet maintained at 12 Upazila Livestock Offices under the "Beef breed development project" of Department of Livestock Services to compare performance between $25 \%$ and $50 \%$ Brahman cross calves. Growth performance traits were considered birth weight, weight at three-, six-, nine-, twelve-month of age, average daily gain from birth to twelve-month of age. Calving difficulties (dystocia) and calf mortality were also included in the study area. The birth weight, weight at three-, six-, nine- and twelve-month average daily gain for $25 \%$ Brahman cross calves were $19.79 \pm 0.20,52.72 \pm 1.31,86.61 \pm 2.02,129.90 \pm 3.08,172.60 \pm 3.48 \mathrm{~kg}$ and $426.00 \pm 4.99 \mathrm{~g}$, respectively. The average birth weight $(21.40 \pm 0.24 \mathrm{~kg})$ and twelve-month weight $(229.62 \pm 2.08 \mathrm{~kg})$ of $50 \%$ Brahman cross calves were significantly higher $(\mathrm{p}<0.05)$ than $25 \%$ Brahman cross calves. Average daily gain was significantly higher $(570.52 \pm 5.19 \mathrm{~g})$ in $50 \%$ Brahman cross than $25 \%$ Brahman cross calves $(529.98 \pm 4.54 \mathrm{~g})$. Birth weight, three-, six-, nine-, twelve-month weight were positively correlated to each other. Strong correlations were found between birth weight and three-month weight (0.65), between six- and nine-month (0.65).There was no report of calving difficulties or abnormal calf birth, where the average calf mortality rate was 2.96 in the study areas. It indicates that $50 \%$ Brahman cross calves were well performed in these climatic condition. However, further study with larger sample sizes covering more different management systems would be required to draw a better conclusion in this regard.
\end{abstract}

Keywords: Brahman cross calves; growth performance; phenotypic correlations

\footnotetext{
1. Introduction

The cattle genetic resources (23.58 million, BER, 2015) of Bangladesh are mostly of indigenous type (Bos indicus) with substantial number of crossbreds with Sindhi, Sahiwal and Holstein-Friesian. Indigenous cattle of the country are more disease resistant and capable to thrive in harsh condition (Majid et al., 1992). In spite of a high density of cattle population, but the protein requirements of the people remain under nourished. According to Department of Livestock Services (DLS, 2005), the availability of meat is $21 \mathrm{~g} / \mathrm{d}$ per head against the requirements of $120 \mathrm{~g} / \mathrm{d}$ per head. So, it is clear that there is a huge shortage of meat in Bangladesh for human consumption. As there is no beef type animal in the country, the farmers are frequently being involved in fattening of either local or upgraded dairy crossed bull calves for increasing the beef production in Bangladesh. Moreover, majority of our farmers are more habituated to manage their indigenous stock since being poor and following low input management system. Considering weather, agro-climatic condition, heat tolerance, disease and parasites resistance, longevity, grazing ability, calving ease, mothering ability and management, Brahman breed is considered to be the most suitable and compatible beef breed in tropical and sub-tropical regions
} 
(Antonio et al., 2006). In this socio-economic condition, upgraded Brahman crossed bull may be more adaptable to our agro-climatic condition owing to improvement of indigenous cattle for beef production. Considering the above circumstances, the experiment was undertaken to evaluate the growth performance of $25 \%$ and $50 \%$ Brahman crossbred calves to local environment of Bangladesh.

\section{Materials and Methods}

\subsection{Location of experiment}

The present experiment was conducted at three different villages namely Boera, Bhabakhali and Dowhakhula under Mymensingh district, Bangladesh.

\subsection{Management of the research activities}

Four Brahman crossbred (graded) breeding bulls had been selected (Bull ID: ABG011, ABG012, ABG013 and ABG014) on the basis of their average daily gain, physical appearance and libido. The selected bulls have been reared at the Artificial Insemination Center, Bangladesh Agricultural University for semen collection. Collected semen of these bulls has been used to inseminate the indigenous cow to improve beef production potentialities in the respective areas. Calves produced from these crossing are considered experimental animal in this study.

\subsection{Data collection}

The data were collected from 624 Brahman cross $(25 \%)$ calves on the growth performance, where male and female calves were 385 and 239 in number. Besides, growth performance data of 289 Brahman cross (50\%) calves were collected from (CCBDF, Chirirbandor, Pirganj, Shariakandi, Belkuchi, Chouhali, Tungipara, Kustia, Jessore, Moulovibazar, Charghat and Thakurgaon where the number of calves was $63,22,46,11,12$, $19,15,10,13,16,18$ and 44, respectively) the data sheet maintained at the Upazila Livestock Office under the "Beef breed development project" of DLS to compare the performance between 25\% and 50\% Brahman cross calves to local environment of the country. Record on birth weight, twelve month weight and average daily gain of $25 \%$ and $50 \%$ Brahman cross calves were taken until June, 2015. Weight of each animal at different ages was measured by using a digital weighing balance. Average daily gain (birth to twelve month age) was calculated in gram $(\mathrm{g})$ by using the following formula:

Average daily gain $(\mathrm{g})=\frac{\text { Final weight }- \text { Initial weight }}{365}$

\subsection{Statistical analysis}

After completing the pre-tabulation task of the collected data, records of crossbred progenies were entered in Excel sheets of Microsoft office computer program. The collected data were tested for their normal distribution using Statistical Analysis System (SAS, Version 6.12) method and abnormal data were omitted from the data sheets. The sorted data were analyzed to obtain results of ANOVA by using Statistical Analysis System (SAS, 1998) computer package. DUNCAN test was performed to separate mean values in case of significant factors.

\section{Results}

\subsection{Birth weight of $25 \%$ Brahman cross calves}

The mean along with standard errors of birth weight of $25 \%$ Brahman cross calves at different areas are shown in Table 1. Analysis of pooled data indicated that area had significant $(\mathrm{p}<0.05)$ effect on birth weight of calves. The birth weight was higher in Bhabakhali $(20.17 \pm 0.06 \mathrm{~kg})$ than those of Boera $(19.75 \pm 0.13 \mathrm{~kg})$ and Dowhakhula (19.47 \pm 0.09$)$.

Table 1. Mean \pm SE of birth weight of $25 \%$ Brahman cross calves in different study areas.

\begin{tabular}{llll}
\hline Area & Boera & Bhabakhali & Dowhakhula \\
\hline Pooled & $19.75^{\mathrm{b}} \pm 0.13(135)$ & $20.17^{\mathrm{a}} \pm 0.06(263)$ & $19.47^{\mathrm{b}} \pm 0.09(226)$ \\
Male & $20.30^{\mathrm{a}} \pm 0.12(92)$ & $20.75^{\mathrm{b}} \pm 0.06(161)$ & $19.72^{\mathrm{b}} \pm 0.09(132)$ \\
Female & $18.60^{\mathrm{a}} \pm 0.14(43)$ & $19.25^{\mathrm{b}} \pm 0.11(102)$ & $19.12^{\mathrm{b}} \pm 0.04(94)$ \\
\hline
\end{tabular}

Figures in the parentheses indicate the number of observation; Means with uncommon superscripts within the same row differed significantly $(\mathrm{p}<0.05)$.

\subsection{Weight at different ages}

Table 2 showed that three month weight of male calves significantly $(\mathrm{p}<0.01)$ affected by areas and males of 
Bhabakhali had higher three-month weight $(55.60 \pm 0.76 \mathrm{~kg})$ than the three-month weights at others areas (53.30 \pm 1.20 and $51.70 \pm 1.33 \mathrm{~kg}$ for Boera and Dowhakhula, respectively).

Table 2. Three-month weight (Mean \pm SE) of $25 \%$ Brahman cross calves in different areas.

\begin{tabular}{llll}
\hline Area & Boera & Bhabakhali & Dowhakhula \\
\hline Pooled & $53.08^{\mathrm{a}} \pm 1.02(135)$ & $54.79^{\mathrm{a}} \pm 0.74(263)$ & $50.29^{\mathrm{b}} \pm 0.77(226)$ \\
Male & $53.30^{\mathrm{b}} \pm 1.20(92)$ & $55.60^{\mathrm{a}} \pm 0.76(161)$ & $51.70^{\mathrm{b}} \pm 1.33(132)$ \\
Female & $52.60^{\mathrm{a}} \pm 2.38(43)$ & $53.50^{\mathrm{a}} \pm 4.50(102)$ & $48.30^{\mathrm{b}} \pm 0.59(94)$ \\
\hline
\end{tabular}

Figures in the parentheses indicate the number of observation; Means with uncommon superscripts within the same row differed significantly $(\mathrm{p}<0.01)$.

Analysis indicated that area had significant $(\mathrm{p}<0.01)$ effect on six-month weight of pooled data as well as sixmonth weight of male and female calves (Table 3). The highest weight at six-month of male calves $(91.10 \pm 0.96$ $\mathrm{kg}$ ) was observed in Bhabakhali than those of other two areas $(86.40 \pm 1.55$ and $84.90 \pm 1.55 \mathrm{~kg})$ for Boera and Dowhakhula, respectively (Table 3).

Table 3. Mean \pm SE at six-month body weight of $25 \%$ Brahman calves in different study areas.

\begin{tabular}{llll}
\hline Area & Boera & Bhabakhali & Dowhakhula \\
\hline Pooled & $85.75^{\mathrm{b}} \pm 1.36(135)$ & $90.48^{\mathrm{a}} \pm 0.94(263)$ & $83.61^{\mathrm{b}} \pm 0.96(226)$ \\
Male & $86.40^{\mathrm{b}} \pm 1.55(92)$ & $91.10^{\mathrm{a}} \pm 0.96(161)$ & $84.90^{\mathrm{b}} \pm 1.55(132)$ \\
Female & $84.37^{\mathrm{a}} \pm 2.86(43)$ & $89.50^{\mathrm{b}} \pm 1.0(102)$ & $81.80^{\mathrm{a}} \pm 0.84(94)$ \\
\hline
\end{tabular}

Figures in the parentheses indicate the number of observation; Means with uncommon superscripts within the same row differed significantly $(\mathrm{p}<0.01)$

The Table evident that areas significantly $(\mathrm{p}<0.01)$ effected on nine-month weight of male calves as well as female calves (Table 4). Males of Bhabakhali had higher weight $(136.12 \pm 1.30 \mathrm{~kg})$ than the other two areas (129.80 \pm 1.98 and 126.30 \pm 1.76$)$ for Boera and Dowhakhula, respectively (Table 4).

Table 4. Mean \pm SE at nine-month weight of $25 \%$ Brahman cross calves in study areas.

\begin{tabular}{llll}
\hline Area & Boera & Bhabakhali & Dowhakhula \\
\hline Pooled & $130.89^{\mathrm{a}} \pm 1.69(132)$ & $134.68^{\mathrm{a}} \pm 1.27(263)$ & $124.14^{\mathrm{b}} \pm 1.31(226)$ \\
Male & $129.80^{\mathrm{b}} \pm 1.98(92)$ & $136.12^{\mathrm{a}} \pm 1.30(161)$ & $126.30^{\mathrm{b}} \pm 1.76(132)$ \\
Female & $124.01^{\mathrm{a}} \pm 1.38(43)$ & $132.43^{\mathrm{b}} \pm 2.00(102)$ & $121.10^{\mathrm{a}} \pm 1.28(94)$ \\
\hline
\end{tabular}

Figures in the parentheses indicate the number of observation; Means with uncommon superscripts within the same row differed significantly $(\mathrm{p}<0.01)$.

Results showed that area had significant $(\mathrm{p}<0.01)$ influence on twelve-month weight of male and female calves (Table 5). Males of Bhabakhali had higher twelve-month weight $(184.60 \pm 1.99 \mathrm{~kg})$ than those of Boera $(174.10 \pm 2.94 \mathrm{~kg})$ and Dowhakhula $(169.50 \pm 2.78 \mathrm{~kg})$ regions (Table 5).

Table 5. Twelve-month weights (Mean \pm SE) of $25 \%$ Brahman cross calves in study areas.

\begin{tabular}{llll}
\hline Area & Boera & Bhabakhali & Dowhakhula \\
\hline Pooled & $171.74^{\mathrm{b}} \pm 2.47(135)$ & $179.03^{\mathrm{a}} \pm 1.95(263)$ & $167.05^{\mathrm{b}} \pm 1.93(226)$ \\
Male & $174.10^{\mathrm{b}} \pm 2.94(92)$ & $184.60^{\mathrm{a}} \pm 1.99(161)$ & $169.50^{\mathrm{b}} \pm 2.78(132)$ \\
Female & $166.70^{\mathrm{a}} \pm 4.22(43)$ & $170.23^{\mathrm{a}} \pm 2.0(102)$ & $163.60^{\mathrm{b}} \pm 1.90(94)$ \\
\hline
\end{tabular}

Figures in the parentheses indicate the number of observation; Means with uncommon superscripts within the same row differed significantly $(\mathrm{p}<0.01)$.

\subsection{Average daily gain}

The mean along with standard errors of average daily gain of $25 \%$ Brahman cross calves of different areas were significantly affected $(\mathrm{p}<0.01)$. Results also showed that males of Bhabakhali had highest average daily gain $(449.94 \pm 25.43 \mathrm{~g} / \mathrm{d})$ and lowest $(408.90 \pm 27.46 \mathrm{~g} / \mathrm{d})$ in Dowhakhula area (Table 6). 
Table 6. Mean $\pm \mathrm{SE}$ of average daily gain (g) up to twelve-month age of $25 \%$ Brahman cross calves.

\begin{tabular}{llll}
\hline Area & Boera & Bhabakhali & Dowhakhula \\
\hline Pooled & $416.35^{\mathrm{b}} \pm 22.13(135)$ & $446.51^{\mathrm{a}} \pm 16.40(263)$ & $403.58^{\mathrm{b}} \pm 16.82(226)$ \\
Male & $421.24^{\mathrm{b}} \pm 27.89(92)$ & $449.94^{\mathrm{a}} \pm 25.43(161)$ & $408.90^{\mathrm{c}} \pm 27.46(132)$ \\
Female & $405.90^{\mathrm{b}} \pm 31.51(43)$ & $441.10^{\mathrm{a}} \pm 24.50(102)$ & $396.10^{\mathrm{c}} \pm 25.15(94)$ \\
\hline
\end{tabular}

Figures in the parentheses indicate the number of observation; Means with uncommon superscripts within the same row differed significantly $(\mathrm{p}<0.01)$.

\subsection{Growth performances of $25 \%$ Brahman cross calves}

Growth performances (birth weight, three-, six-, nine-, twelve- month weight and average daily gain) of Brahman cross male calves (ignoring area and bull effect) were higher than those of female calves (Table 7).

Table 7. Mean \pm SE of weight $(\mathrm{kg})$ at different age of $25 \%$ Brahman cross male and female calves.

\begin{tabular}{lllllll}
\hline Trait & BWT & WT3 & WT6 & WT9 & WT12 & ADG12 \\
\hline Pooled & $19.79 \pm 20$ & $52.72 \pm 1.31$ & $86.61 \pm 2.02$ & $129.90 \pm 3.08$ & $172.60 \pm 3.48$ & $428.81 \pm 19.20$ \\
Male & $20.25^{\mathrm{a}} \pm 0.29$ & $53.53^{\mathrm{a}} \pm 1.13$ & $87.46^{\mathrm{a}} \pm 1.86$ & $130.74^{\mathrm{a}} \pm 2.87$ & $176.06^{\mathrm{a}} \pm 4.46$ & $426.69^{\mathrm{a}} \pm 12.15$ \\
Female & $18.99^{\mathrm{b}} \pm 0.19$ & $51.46^{\mathrm{b}} \pm 1.60$ & $85.22^{\mathrm{b}} \pm 2.26$ & $125.84^{\mathrm{b}} \pm 3.39$ & $166.84^{\mathrm{b}} \pm 1.91$ & $414.36^{\mathrm{b}} \pm 13.66$ \\
\hline
\end{tabular}

n, number of observation; BWT, birth weight; WT3, three-month weight; WT6, six-month weight; WT9, nine-month weight; WT12, twelve-month weight; ADG12, average daily gain; Means with uncommon superscripts between male and female within same trait of the column differed significantly.

\subsection{Growth performances of $50 \%$ Brahman cross calves}

Mean along with their standard error of birth weight, twelve-month weight and average daily gain of 50\% Brahman cross calves are shown in Table 8. The average birth weight of total calves was $(21.40 \pm 0.24 \mathrm{~kg}) \mathrm{where}$ sex has a large effect on birth weight of calves. The average birth weight of male was $(22.50 \pm 0.36 \mathrm{~kg}) \mathrm{which}$ is higher than females birth weight $(20.24 \pm 0.29 \mathrm{~kg})$ which shows male calves were heavier than females, and weak calves tended to be lighter than healthy calves. The mean twelve-month weight of Brahman crossbred calves was $(229.62 \pm 2.08 \mathrm{~kg})$ and male calves had slightly higher twelve-month weight than that of female calves (male $245.13 \pm 2.88$ vs. female $213.10 \pm 2.29 \mathrm{~kg}$ ). The overall mean of average daily gain of crossbred calves was $(570.52 \pm 5.19 \mathrm{~g} / \mathrm{d})$ and it was influenced by sex. Average daily gain of male was $(610.12 \pm 7.11 \mathrm{~g} / \mathrm{d})$ and in female it was $(528.38 \pm 5.77 \mathrm{~g} / \mathrm{d})$.

Table 8. Mean $\pm \mathrm{SE}$ of birth and twelve-month weight and average daily gain of total Brahman graded $(50 \%)$ calves.

\begin{tabular}{llll}
\hline Parameter & Pooled & Male & Female \\
\hline BWT $(\mathrm{kg})$ & $21.40 \pm 0.24(289)$ & $22.50^{\mathrm{a}} \pm 0.36(149)$ & $20.24^{\mathrm{b}} \pm 0.29(140)$ \\
WT12 $(\mathrm{kg})$ & $229.62^{\mathrm{b}} \pm 2.08(289)$ & $245.13^{\mathrm{a}} \pm 2.88(149)$ & $213.10^{\mathrm{c}} \pm 2.29(140)$ \\
ADG $(\mathrm{g} / \mathrm{d})$ & $570.52^{\mathrm{b}} \pm 5.19(289)$ & $610.12^{\mathrm{a}} \pm 7.11(149)$ & $528.38^{\mathrm{c}} \pm 5.77(140)$ \\
\hline
\end{tabular}

Figures in the parentheses indicate the number of observation; BWT, birth weight; WT12, twelve-month weight; and ADG, average daily gain; means with different superscripts in the same raw differed significantly $(\mathrm{p}<0.001)$.

\subsection{Comparison of growth traits between $25 \%$ and $50 \%$ Brahman calves}

Comparison among growth traits between 25\% and 50\% Brahman calves are shown in Table 9. The pooled data average of birth weight of Brahman calves was $(19.73 \pm 0.12 \mathrm{~kg}$ ). The average birth weight of $50 \%$ Brahman cross calves was $(21.40 \pm 0.24 \mathrm{~kg})$ which was higher than the birth weight $(18.59 \pm 0.08 \mathrm{~kg})$ of $25 \%$ Brahman cross calves which shows $50 \%$ Brahman calves were heavier than $25 \%$ Brahman. The mean twelve-month weight of Brahman crossbred calves was $(217.55 \pm 1.38 \mathrm{~kg})$ and $50 \%$ Brahman calves had slightly higher twelvemonth weight than that of $25 \%$ Brahman cross calves $(50 \%$ Brahman, 229.62 \pm 2.08 vs. 25\% Brahman, $209.29 \pm 1.74 \mathrm{~kg}$ ). The overall mean of average daily gain of Brahman cross calves was $546.46 \pm 3.50 \mathrm{~g} / \mathrm{d}$ ). Average daily gain of $25 \%$ Brahman cross calves was $(529.98 \pm 4.54 \mathrm{~g} / \mathrm{d})$ and $50 \%$ Brahman cross calves was $(570.52 \pm 5.19 \mathrm{~g} / \mathrm{d})$. 
Table 9. Comparison among growth traits between $25 \%$ and $50 \%$ Brahman cross calves.

\begin{tabular}{llll}
\hline \multirow{2}{*}{ Growth trait } & \multicolumn{2}{c}{ Brahman calves } \\
\cline { 2 - 4 } & Pooled $(\mathbf{9 1 3})$ & $\mathbf{2 5 \%}(\mathbf{6 2 4})$ & $\mathbf{5 0 \%}(\mathbf{2 8 9})$ \\
\hline BWT $(\mathrm{kg})$ & $19.73 \pm 0.12$ & $18.59^{\mathrm{b}} \pm 0.08$ & $21.40^{\mathrm{a}} \pm 0.24$ \\
WT12(kg) & $217.55^{\mathrm{b}} \pm 1.38$ & $209.29^{\mathrm{c}} \pm 1.74$ & $229.62^{\mathrm{a}} \pm 2.08$ \\
ADG $(\mathrm{g} / \mathrm{d})$ & $546.46^{\mathrm{b}} \pm 3.50$ & $529.98^{\mathrm{c}} \pm 4.54$ & $570.52^{\mathrm{a}} \pm 5.19$ \\
\hline
\end{tabular}

Figures in the parentheses indicate the number of observation; BWT, birth weight; WT12, twelve-month weight; ADG, average daily gain; means with different superscripts between $50 \%$ and $25 \%$ Brahman calves in the same row differed significantly $(\mathrm{p}<0.001)$.

\subsection{Calving difficulties and calf mortality}

There was no report of calving difficulties (dystocia) or abnormal calf born in study areas. The calf mortality (Table 10) was found in Boera (3.13\%) was slightly higher than those of Bhabakhali (2.71\%) and Dowhakhola $(3.06 \%)$. The average calf mortality rate was found as $2.96 \%$.

Table 10. Calf mortality up to twelve-month of age at different study areas.

\begin{tabular}{lllll}
\hline Area & Boera & Bhabakhali & Dowhakhula & Total \\
\hline Calf born & 192 & 332 & 259 & 833 \\
Calf died & 6 & 9 & 8 & 23 \\
Mortality $(\%)$ & 3.13 & 2.71 & 3.06 & 2.96 \\
\hline
\end{tabular}

\subsection{Correlation among growth of different ages of calves}

Phenotypic correlations among the body weight traits of Brahman cross calves at different ages are summarized in Table 11. Birth weight, three-, six-, nine-, twelve-month weight and average daily gain all are positively correlated to each other. Strong correlations were found between birth weight and weight at three-month (0.65), between weights at six- and nine-month (0.65).

Table 11. Phenotypic correlations among body weight of $25 \%$ Brahman cross calves at different ages.

\begin{tabular}{lllll}
\hline Growth trait & WT3 & WT6 & WT9 & WT12 \\
\hline BWT & 0.65 & 0.52 & 0.63 & 0.48 \\
WT3 & & 0.60 & 0.62 & 0.45 \\
WT6 & & 0.65 & 0.45 \\
WT9 & & & 0.43 \\
\hline
\end{tabular}

BWT, birth weight; WT3, three-month weight; WT6, six-month weight; WT9, nine-month weight; WT12, twelve-month weight.

\section{Discussion}

\subsection{Birth weight of calves}

The mean birth weight of $25 \%$ and $50 \%$ Brahman male and female calves were $20.25 \pm 0.29,18.99 \pm 0.19$ and $22.50 \pm 0.36,20.24 \pm 0.29 \mathrm{~kg}$, respectively. The value of birth weight of the present study were comparable to the value $(23.3 \mathrm{~kg}$ ) observed by Crockett et al. (1978) for beef cattle. Holloway et al. (2005) observed $33.50 \mathrm{~kg}$ birth weight of Brahman and Angus crosses, which was much higher than the value of the present findings. This variation was probably due to use of Brahman bulls for crossing with the dams those were genetically superior to indigenous cattle and genetic proportion of Brahman sires. Birth weight of male calves was $2.25 \mathrm{~kg}$ higher than female calves $(1.25 \mathrm{~kg})$ which are similar to the values $(2.1 \mathrm{~kg}$ and $2.00 \mathrm{~kg})$ observed by Vargas et al. (1999) and Keith et al. (2010), respectively.

The average birth weight of $50 \%$ Brahman cross calves was $(21.40 \pm 0.24 \mathrm{~kg})$ higher than the calves of $25 \%$ Brahman cross (18.59 \pm 0.08$)$. It was proved that sex had significant $(\mathrm{p}<0.001)$ effects on birth weight of $50 \%$ Brahman cross calves. From the above discussion it is clear that the average birth weight of 50\% Brahman with local crossed calves were higher than the birth weight of $25 \%$ Brahman with local cows. This might be due to cumulative effects of better growth potential genes of pure Brahman cattle than crossbred Brahman. 


\subsection{Weight at different ages}

The mean three-month weight of $25 \%$ Brahman male and female calves was $53.53 \pm 1.13$ and $51.46 \pm 1.60 \mathrm{~kg}$, respectively. The weight of Brahman cross calves was higher than that reported by Aruna et al. (2004), Gaur et al. (2003) which were $59.38 \mathrm{~kg}$ for Karan Fries and $54.25 \mathrm{~kg}$ for crossbred, respectively.

The six-month weight of $25 \%$ Brahman cross male and female calves was $87.46 \pm 1.86$ and $85.22 \pm 2.26 \mathrm{~kg}$, respectively. The weight of this study was found much lower than the findings reported by Chen et al. (2012) of Piedmontese and Nanyang as $194 \mathrm{~kg}$, while the six-month weight of this study was found higher than that reported by Gaur et al. (2003) and Carew et al. (1986) which were $85.8 \mathrm{~kg}$ for crossbred and $71.4 \mathrm{~kg}$ for crossbred, respectively.

The nine month weight of $25 \%$ Brahman male and female cross calves was $130.74 \pm 2.87$ and $125.84 \pm 3.39 \mathrm{~kg}$, respectively which was found much lower than the findings reported by Chen et al. (2012) of Piedmontese and Nanyang as $293 \mathrm{~kg}$, Neser et al. (2012) of Brangus as $227.6 \mathrm{~kg}$, respectively, while the nine-month weight of this study was found higher than that reported by Gaur et al. (2003) and Carew et al. (1986) which were 125.56 and $123.0 \mathrm{~kg}$ for crossbred, respectively.

The mean twelve-month weight of 50\% Brahman cross calves was $229.62 \pm 2.08 \mathrm{~kg}$, which was higher than that of $25 \%$ Brahman cross calves. This result was lower than that of $248 \mathrm{~kg}$ by Holloway et al. (2005) in Brahman and Angus cross.

\subsection{Average daily gain}

The mean average daily weight gain of $25 \%$ Brahman cross calves was $426.69 \pm 12.15 \mathrm{~g}$ for male and $414.36 \pm 13.66 \mathrm{~g}$ for female, respectively which is significantly $(\mathrm{p}<0.01)$ affected by area and sex on average daily gain up to one year of age. The mean average daily weight gain of $50 \%$ Brahman cross calves was $570.52 \pm 5.19 \mathrm{~g}$ which is significantly $(\mathrm{p}<0.001)$ affected by sex. This result was similar to Antonio et al. (2006) who reported mean average daily gain of calves to be $429 \mathrm{~g}$ in summer season. Keith et al. (2010) and Colditz et al. (1972) reported higher average daily weight gain than that of the present study ( $849 \mathrm{~g}$ and $670 \mathrm{~g})$. These are probably due to genotype and environmental variations, feeding system and evidently proved that $50 \%$ Brahman crossed calves are better than the calves from 25\% Brahman cross types of Bangladesh.

\subsection{Calving difficulties and calf mortality}

There were no reports of calving difficulties (dystocia) or abnormal calf born in study areas. Mortality rate (2.96) was found in the study areas which were higher than that of Brahman-sired cows $2.4 \%$ in Simmental observed by Morrison et al. (1989).

\subsection{Phenotypic correlations}

Strong phenotypic correlations were found between birth weight and weight at three-month (0.65), between weights at six- and nine-month (0.65) which indicated that selection based of body weight at one stage of growth will also improve the body weight at other stages.

\section{Conclusions}

The weight at different stages of growth of $25 \%$ Brahman cross calves at Bhabakhali were higher than that of other two areas, which indicating that farmers of Bhabakhali may provide better feeding and management to their calves. The variations of results between progeny of different bulls might be due to variation in genetic potentialities of different breeding bulls, as well as individual differences for feeding and management. Strong phenotypic correlations were found between birth weight and weight at three-month. The birth weight, twelvemonth weight and average daily gain of 50\% Brahman crossed calves were higher than that of $25 \%$ Brahman cross calves in Bangladesh. As the Brahman crossed cattle are a new introduction to Bangladesh, further in depth study is needed to explore more information from breed development approaches.

\section{Acknowledgements}

The authors express his thanks to the Department of Animal Breeding and Genetics, technicians and farmers of the study areas for their kind cooperation, friendly attitude and inspiration throughout the research work.

\section{Conflict of interest}

None to declare. 


\section{References}

Antonio JLH, R Owen and O Timothy, 2004. Pre-weaning traits of Brahman calves under a dual-purpose management system in the tropics. Rev. Cien., 4: 344-353.

Aruna P, AK Chakravarty, TK Bhattacharya, BK Joshi and A Sharma, 2004. Detection of polymorphism of growth hormone gene for the analysis of relationship between allele type and growth traits in Karan Fries cattle. Asian-Aust. J. Anim. Sci., 17:1334-1337.

BER (Bangladesh Economic Review), 2015. Finance Division, Ministry of Finance, Government of the People's Republic of Bangladesh.

Carew SF, J Sandford, YJ Wissocq, J Durkin and JCM Trail, 1986. N'Dama cattle productivity at Teko Livestock Station, Sierra Leone and initial results from crossbreeding with Sahiwal. International Livestock Centre for Africa, Bulletin Number 23.

Chen J, HB Zhu, D Wang, FQ Wang, HS Hao, WH Du and XM Zhao, 2012. Estimation of genetic parameters for growth traits in a crossbred population derived from piedmontese and nanyang cattle using a multi-trait animal model. J. of Anim. and Vet Adv., 11: 1570-1573.

Colditz PJ and RC Kellaway, 1972. The effect of diet and heat stress on feed intake, growth, and nitrogen metabolism in Friesian, $F_{1}$ Brahman $\times$ Friesian and Brahman heifers. Aus. J. of Agri. and Res., 23: 717-725.

Crockett JR, M Koger and DE Franke, 1978. Rotational crossbreeding of beef cattle: Pre-weaning Traits by Generation. J. of Anim. Sci., 46: 1170-1177.

DLS (Department of Livestock Services), 2005. Livestock statistics of Bangladesh. Ministry of Fisheries and Livestock, Govt. of the Peoples Republic of Bangladesh.

Guar OK, SN Kaushik and RC Garg, 2003. The Gir cattle breed of India, characteristics and present status. Anim. Gen. Res. Info., 33: 21-29.

Holloway JW, BG Warrington, DW Forrest and RD Randel, 2005. Lifetime performance and efficiency of $\mathrm{F}_{1}$ tropically adapted beef cattle breeds $\times$ Angus in semiarid rangeland, Texas Agricultural Experiment Station, Uvalde, College Station and Overton.

Keith E, Gregory, GM Smith, LV Cundiff, RM Koch and DB Laster, 2010. Characterization of biological types of cattle-cycle birth and weaning traits. J. of Anim. Sci., 48:271-279.

Majid MA, TN Nahar and MA Jalil, 1992. Breeding for cattle improvement in Bangladesh. Proceedings of the $4^{\text {th }}$ National Conference, Bangladesh Animal Husbandry Association. pp. 169-181.

Morrison DG, PE Humes and KL Koonce, 1989. Comparison of Brahman and continental European crossbred cows for calving ease in a subtropical environment. J. of Anim. Sci., 67: 1722-1731.

Neser FWC, Wyk JB Van, MD Fair, P Lubout and BJ Crook, 2012. Estimation of genetic parameters for growth traits in Brangus cattle. Peer-reviewed paper: Proceedings of the $44^{\text {th }}$ Congress of the South African Society for Animal Science. South Afr. J. of Anim. Sci., 42.

SAS (Statistical Analysis System), 1998. User's guide. SAS Institute Inc. Version 6.12. Cary, United States of America.

Vargas CA, MA Elzo, CCJ Chase, PJ Chenoweth and TA Olson, 1999. Estimation of genetic parameters for scrotal circumference, age at puberty in heifers, and hip height in Brahman cattle. J. of Anim. Sci., 76: 25362541. 